Volume 12

Issue 2 Images And Collective Violence:

Function, Use And Memory

$10-2018$

\title{
The Unbribable Witness: Image, Word, and Testimony of Crimes against Humanity in Mark Twain's King Leopold's Soliloquy (1905)
}

Nora Nunn

Duke University

Follow this and additional works at: https://digitalcommons.usf.edu/gsp

\section{Recommended Citation}

Nunn, Nora (2018) "The Unbribable Witness: Image, Word, and Testimony of Crimes against Humanity in Mark Twain's King Leopold's Soliloquy (1905)," Genocide Studies and Prevention: An International Journal: Vol. 12: Iss. 2: 84-106.

DOI:

https://doi.org/10.5038/1911-9933.12.2.1525

Available at: https://digitalcommons.usf.edu/gsp/vol12/iss2/7

This Articles is brought to you for free and open access by the Open Access Journals at Digital Commons @ University of South Florida. It has been accepted for inclusion in Genocide Studies and Prevention: An International Journal by an authorized editor of Digital Commons @ University of South Florida. For more information, please contact digitalcommons@usf.edu. 


\title{
The Unbribable Witness: Image, Word, and Testimony of Crimes against Humanity in Mark Twain's King Leopold's Soliloquy (1905)
}

\author{
Nora Nunn \\ Duke University \\ Durham, North Carolina, USA
}

\section{Introduction}

In 1904, Edmund Dene Morel, co-founder of the British-based Congo Reform Association (CRA), put faith in the power of written language and visual imagery when he asked Mark Twain to brandish his sword-like pen for "the cause of the Congo natives." 1 As its title suggests, the resulting work, King Leopold's Soliloquy: A Defense of His Congo Rule, puts its readers in imaginative proximity to the machinations of the Belgian despot. Twain, known for his anti-imperialist work such as the 1897 collection Following the Equator, chose to depict Leopold II as a bloodthirsty monomaniac of Shakespearean proportions. Like his peers in the CRA, the American writer realized the power of visual cultures to craft his narrative, insisting on the juxtaposition of graphic imagery with the written word. Though a slender 58 pages, the kaleidoscopic document circumnavigates the globe, from the king's opulent palace in Brussels to rubber-collection stations in the Congo Free State - a swath of land more than 70 times larger than Belgium. At times, its visual style is phantasmagoric, as in the case of a ghoulish drawing in which Leopold greedily clings to bags of gold, daydreaming of Congolese amputation. In other moments, the text shifts into a more documentary mode; several images, based on eyewitness photographs obtained by European and American missionaries, portray nightmarish scenes, including the smoking of several amputated right hands over a fire. Other woodcut prints of limbless children, or, inversely, severed limbs, also provide stark visual proof of collective colonial violence.

Such evidential images were reproduced from those taken by the Kodak camera, or the "only witness," Twain's imagined Leopold ruefully fumes, that he "couldn't bribe." ${ }^{2}$ In tandem with their written captions, these images of mutilation and its aftermath provided a way to contest Leopold's well-oiled propaganda machine, which exploited the rhetoric of philanthropy to claim the Congo Free State as a "humanitarian" venture that would "pierce the darkness of barbarism" in Africa. ${ }^{3}$ As Sir Arthur Conan Doyle observed in the preface to his own contribution to the reformist cause, The Crime of the Congo, a gruesome reality belied Leopold's altruistic appearances: "never before has there been such a mixture of wholesale expropriation and wholesale massacre all done under an odious guise of philanthropy."4 Enter stage left: the king's nemesis, Mark Twain. His weapons were the same, but his goal was radically different.

By enlisting a palimpsest of mediums and genres, both written and visual, in King Leopold's Soliloquy, Twain sought to convey what Achille Mbembe calls colonialism's "topographies of cruelty," or the ways in which the living were systematically subjected to terror and death. ${ }^{5}$ As visual historian Sharon Sliwinski points out, the CRA was the first international humanitarian movement to mobilize atrocity photographs as a tool for social and political change. ${ }^{6},{ }^{7}$ A soldier of

\footnotetext{
${ }^{1}$ Stefan Heym, introduction to King Leopold's Soliloquy, by Mark Twain (New York: International Publishers, 2014 ), 17.

${ }^{2}$ Mark Twain, King Leopold's Soliloquy: A Defense of His Congo Rule, 2nd ed. (Boston: P.R. Warren, 1905), 39-40. In referring to the camera as "the Kodak," Twain used a brand name as a generic name; in actuality, several of the images heavily enlisted by the CRA were not taken by Kodak cameras, which had become popular after their release by American entrepreneur George Eastman's company in 1888. For instance, Alice Harris, the British missionary who took some of the most famous images of atrocities in the Congo Free State, used a dry plate box camera instead of a Kodak. See Kevin Grant, "The Limits of Exposure: Atrocity Photographs in the Congo Reform Campaign," in Humanitarian Photography: A History, ed. Heide Fehrenbach and Davide Rodogno (New York: Oxford University Press, 2015$), 67$.

${ }^{3}$ Marouf Hasian, Jr., "Alice Seeley Harris, the Atrocity Rhetoric of the Congo Reform Movements, and the Demise of King Léopolds's Congo Free State," Atlantic Journal of Communication 23, no. 3 (2015), 181.

${ }^{4}$ Sir Arthur Conan Doyle, The Crime of the Congo (New York: Doubleday, Page \& Company, 1909), iii.

${ }^{5}$ Achille Mbembe, "Necropolitics," Public Culture 15, no. 1 (2003), 40.

${ }^{6}$ Sharon Sliwinski, "The Childhood of Human Rights: The Kodak on the Congo," Journal of Visual Culture 5, no. 3 (2006), 334.

${ }^{7}$ Still, as Christina Twomey reminds us, the CRA's narrative strategies did not emerge from thin air. After all, the CRA built on the international humanitarian rhetoric of $19^{\text {th }}$-century historical precedents such as the Bulgarian atrocities
} 
this campaign, Twain mustered a hodgepodge of materials in his case against Leopold: photographic journalism, sketches, cartoons, diary extracts, Juvenalian satire, poetry, Shakespearean soliloquy, and late 19th century human rights rhetoric. In the creation of a textured, visually irrefutable, and darkly satirical account of human rights abuses, he aimed to evoke his audience's empathy by activating their imaginations. If the readers could only understand the extent of colonial violence, the text intimates, then perhaps they could help make possible political interventions in the Congo Free State, which Leopold ruled as his own private domain from 1885 to 1908. At the same time, however, Twain's yoking of dramatic monologue with a patchwork of violent imagery creates a virtual courtroom that interrogates the very limits of human empathy. As if daring readers to prove him wrong, Twain's Leopold gleefully predicts that "the human race" will ultimately "shudder and turn away" from the suffering of others. ${ }^{8}$ Yet, most ironically, while it critiques the American government's failure to intervene in the Congo Free State, King Leopold's Soliloquy remains willfully deaf to the echoes of violence in Twain's own backyard, a nation in which white citizens routinely sent postcards of lynched black citizens, sprawled with messages such as "Warning" or "This is the Barbecue we had last night." 9 These white American spectators did not shudder, but instead turned to face-and actively participate in - the horrific suffering of others.

If, as cultural critic Susan Sontag writes, photographs "haunt us" and narratives can "make us understand," I propose that we consider the political possibilities in the chasm between image and written narrative, haunting and understanding. ${ }^{10}$ Informed by the work of cultural and literary critics including Roland Barthes, Susan Sontag, and Fred Moten, this paper will consider different modes of visual imagery in Twain's text, ranging from documentary to abstract, from realist to phantasmagoric. Read side by side, these images engender questions about fact, testimony, and witnessing in the realm of human rights and collective violence. I argue that the relation (or dissonance) of visual imagery to written text in this relatively unknown and understudied work by Twain yields vital implications for scholars of genocide. I will show how Twain employed to great effect a multisensorial and multigeneric strategy in crafting his narrative with the goal of forcing his readers to reckon with-and ultimately act upon-knowledge of the magnitude, scope, and gravity of Leopold's crimes against humanity. The study of a literary text such as King Leopold's Soliloquy and the responses to its circulation-such as Leopold's propagandist tract, An Answer to Mark Twain-illuminates both the possibilities and the limits of literature in instrumentalizing visual imagery to catalyze political interventions in collective violence.

When founding the field of genocide studies, Raphael Lemkin did not privilege literary or visual studies, instead emphasizing economics, law, history, and sociology as disciplines of relevance to understanding the phenomenon of mass slaughter. To this day, Lemkin's disciplinary myopia continues to leave an imprint on the field: a survey of several genocide anthologies and readers attests to the marginalization of literary studies as compared to the social sciences. ${ }^{11}$ A consideration of literary works such as Twain's underscores the value of a more capacious interdisciplinary approach to genocide studies, especially since Lemkin himself included the Belgian Congo in his unfinished and unpublished multi-volume history of crime. ${ }^{12}$ This epic war of stories surrounding the Congo Free State-Twain's versus Leopold's - was a matter of lives and deaths. Mute as it was, the Kodak proved the most formidable witness called to testify against the king.

and the Indian famine of the 1870s: "There was an extant language of atrocity and moral outrage available to Congo reformers that amplified the resonance of their claims." Christina Twomey, "Framing Atrocity: Photography and

Humanitarianism," in Humanitarian Photography: A History, ed. Heide Fehrenbach and Davide Rodogno (New York: Cambridge University Press, 2015), 60.

${ }^{8}$ Twain, King Leopold's Soliloquy, 42.

${ }^{9}$ James Allen et al., Without Sanctuary: Lynching Photography in America, 10th ed. (Santa Fe: Twin Palms Publishers, 2000), $174,186$.

${ }^{10}$ Susan Sontag, Regarding the Pain of Others (New York: Picador, 2003), 89.

${ }^{11}$ For examples of anthologies and genocide readers that either neglect or marginalize literary considerations of the topic, see Adam Jones, Genocide: A Comprehensive Introduction, 3rd ed. (New York: Routledge, 2017); Samuel Totten and Paul R. Bartrop, eds., The Genocide Studies Reader, 1st ed. (New York: Routledge, 2009); Jens Meierhenrich, ed., Genocide: A Reader, 1st ed. (Oxford: Oxford University Press, 2014).

${ }^{12}$ Raphaël Lemkin, Lemkin on Genocide, ed. Steven Leonard Jacobs (Plymouth: Lexington Books, 2012), 18. 


\section{Leopold's Crime Against Humanity}

By 1904, the year in which the CRA was founded by E.D. Morel and Roger Casement in England, several millions had already perished in Central Africa under the murderous rule of the Belgian monarch. Leopold's sadistic regime had inspired Joseph Conrad, who had worked for a Belgian steamer, Roi des Belges, on the Congo River in 1890, to pen his 1899 novella Heart of Darkness as well as the 1897 short story "An Outpost of Progress."13 Of course, other Western witnesses had preceded Morel, Casement, and even Conrad in publicizing their outrage over the systematic atrocities - the mutilation of limbs, the flagellation of flesh, and the systematic execution of rubber plantation laborers - occurring in the Congo Free State. In fact, it was George Washington Williams, an African American lawyer, Civil War veteran, minister, and journalist, who first applied "crimes against humanity," a phrase that had originated in the early 1800s, in reference to Leopold's rule in $1890 .{ }^{14}$ Shortly before his death, a bone-chilling visit to the Congo Free State compelled Williams to compose an open letter that would make him the first public critic of the king. ${ }^{15}$ He methodically enumerated 12 specific charges against Leopold, including "deceit, fraud, robberies, arson, murder, slave-raiding, and [a] general policy of cruelty." ${ }^{16}$ Williams relied on the written word to relay his eyewitness account: "Your Majesty's Government has sequestered their land, burned their towns, stolen their property, enslaved their women and children, and committed crimes too numerous to mention in detail." ${ }^{\prime 7}$ Much like the tone of Émile Zola's open letter about the Dreyfus Affair (which it anticipated by eight years), Williams' message was unambiguous: $j^{\prime} a c c u s e$ ! First published in The New York Herald and then widely reprinted on both sides of the Atlantic, the letter shares many rhetorical and generic qualities of reports from present-day human rights organizations such as Amnesty International and Human Rights Watch. ${ }^{18}$

Americans and their British counterparts read reports such as Williams' or those of other Western eyewitnesses of the Belgian atrocities in the morning papers. In the evening, these same citizens, especially city dwellers, might conclude the day by attending a touring magic lantern show hosted by Christian missionaries recently returned from the place they had labelled the "Dark Continent." A precursor of the slide projector, the magic lantern projected images painted on a glass plate onto a large screen such as a canvas or sheet, often accompanied by live background music. By the 1880s, it had become common practice for Christian missionaries returning from Africa to leverage the magic lantern show as a tool with which to promote what they called the "civilizing mission" of their work, often with accompanying lectures and religious hymns lasting up to several hours at a time. ${ }^{19}$ Evangelical zeal, white racism, and voyeuristic hunger conspired to gaze upon the "savage" Congolese in need of Western Christian salvation. By grossly exaggerating the polygamy, cannibalism, and slavery practiced in the Congo Free State, the missionaries perpetuated narratives in which the white man was hero-whether a swashbuckling explorer or minister of salvation. Their behavior fits what the writer, photographer, and art historian Teju Cole

\footnotetext{
${ }^{13}$ Adam Hochschild surmises that Conrad at least partly based his character of Kurtz on the Belgian colonial official Léon Rom: "It is from Rom that Conrad may have taken the signal feature of his villain: the collection of African heads surrounding Kurtz's house." See Adam Hochschild, King Leopold's Ghost: A Story of Greed, Terror, and Heroism in Colonial Africa, First Mariner Books ed. (Boston: Houghton Mifflin, 1999), 145.

${ }^{14}$ Ibid., 111-12. See also Dean Pavlakis, British Humanitarianism and the Congo Reform Movement, 1896-1913 (New York: Routledge, 2016), 179.

${ }^{15}$ John Hope Franklin, George Washington Williams: A Biography (Durham: Duke University Press, 1998), 241.

${ }^{16}$ George Washington Williams, "An Open Letter to His Serene Majesty Leopold II, King of the Belgians and Sovereign of the Independent State of Congo, by Colonel the Honorable Geo. W. Williams, of the United States of America," in George Washington Williams: A Biography, by John Hope Franklin (Durham: Duke University Press, 1998), 253.

${ }^{17}$ Ibid., 246.

${ }^{18}$ Sliwinski, The Childhood of Human Rights, 338.

${ }^{19}$ As T. Jack Thompson notes, these magic lantern shows, such as the ones given in Britain by missionary Dr. Harry Guinness, who would later appropriate the technology to expose Leopold's atrocities in the early 1900s, "had something of the same public appeal as a modern rock tour, with thousands of people attending a given lecture." See T. Jack Thompson, Light on Darkness?: Missionary Photography of Africa in the Nineteenth and Early Twentieth Centuries (Grand Rapids: Eerdmans Publishing, 2012), 213, 229-230.
} 
would deem, over a century later, in reference to campaigns such as Kony 2012, the "White-Savior Industrial Complex." ${ }^{20}$

Yet these magic lantern shows of Western witnessing in the Congo Free State also drew from the more supernatural tradition of phantasmagoric theater. Like the magic lantern, the genealogy of phantasmagoria can be traced to Europe-specifically German séances in the late $18^{\text {th }}$ century in which spirits were called back from the dead. The word's etymology yields its necromantic secrets from ancient Greek by way of French: fantasme means ghost, and agoria signifies a place of assembly. ${ }^{21}$ Enlisting the technology of the magic lantern, the phantasmagoric shows trafficked in preternatural horror, projecting optical illusions of ghouls, ghosts, and demons on large screens. During such fantasmagorie, sound effects often accompanied the moving images, which had grown out of the optical experiments conducted by its inventor, Belgian showman and famed balloonist Étienne-Gaspard Robert. Robert's bar for success required that the images capsize his audience's sense of reality: "I am only satisfied if my spectators, shivering and shuddering, raise their hands or cover their eye out of fear or ghosts and devils dashing towards them," he claimed. ${ }^{22}$ By May 1803, the magic lantern had arrived in the United States; throughout the century, the shows, often dabbling in necromancy, continued to voyeuristically titillate-and petrify - giant crowds.

By the dawn of the 20th century, however, reports of the atrocities taking place in the Congo began to circulate, and the tides of support for Leopold began to shift. For example, in 1904 the gruesome crimes documented by Irish diplomat Roger Casement's "The Congo Report" caused a political outcry in Britain. Consequently, in the early 1900s, a phalanx of social activists on both sides of the Atlantic began advocating for reform in the Congo Free State. From New York City to London, these reformers conscripted the magic lantern as a tool with which to publicize visual evidence no longer of Leopold's philanthropy but of his crimes against humanity. ${ }^{23}$ It was Dr. Harry Guinness, a British missionary returning from the Balolo mission, who spearheaded this shift with "A Reign of Terror on the Congo," a collection of magic lantern slides first shown in Scotland in 1903, to expose the Belgian colonial atrocities. ${ }^{24}$ Crowds inundated such sold-out magic lantern shows. After their return from the Baringa mission, John and Alice Harris, a British missionary couple, followed E.D. Morel to the United States addressed more than 200 public meetings in 49 cities. ${ }^{25}$ These double-edged spectacles simultaneously perpetuated stereotypes of the "savagery" of the Congolese in need of Christian conversion and also raised awareness about the atrocities taking place in the Congo Free State. ${ }^{26}$ Like the abolitionist iconography of the late 18th century of which Saidiya Hartman has written, the magic lantern shows "reproduced the abject position" of the African in need of white Christian salvation. ${ }^{27}$

Accompanied by religious music, Christian lectures, and xenophobic zeal, the magic lantern shows straddled the realms of the ethnographic and the supernatural. As Sliwinski notes, these mass public gatherings blurred the line between phantasmagoric and documentary mode:

These highly structured 'shows' could be considered a derivative of phantasmagoria: scripted horror narratives illustrated with 60 photographic slides, of which perhaps a half

\footnotetext{
${ }^{20}$ Teju Cole, "The White-Savior Industrial Complex," The Atlantic, March 21, 2012, accessed July 25, 2017, http://www. theatlantic.com/international/archive/2012/03/the-white-savior-industrial-complex/254843/.

${ }^{21}$ Oxford English Dictionary, s.v. "Phantasmagoria, N.," accessed July 20, 2017, http://www.oed.com.proxy.lib.duke.edu/ view/Entry/142184.

${ }^{22}$ R. Bruce Elder, Harmony and Dissent: Film and Avant-Garde Art Movements in the Early Twentieth Century (Waterloo: Wilfrid Laurier University Press, 2010), 104.

${ }^{23}$ Other social reformers, such as Jacob Riis, author of the muckraking 1890 photographic exposé How the Other Half Lives: Studies among the Tenements of New York, had also enlisted the magic lantern with the goal of inaugurating political interventions, even as he circulated demeaning stereotypes of the denizens of the New York ghettos.

${ }^{24}$ Thompson, Light on Darkness?, 230.

${ }^{25}$ Hochschild, King Leopold's Ghost, 242

${ }^{26}$ Sliwinski, The Childhood of Human Rights, 347.

${ }^{27}$ Saidiya Hartman, Lose Your Mother: A Journey Along the Atlantic Slave Route (New York: Farrar, Straus and Giroux, 2007), 167.
} 
dozen represented various atrocities...interspersed with hymns, prayers, and melodramatic evangelical appeals, all of which meant to elicit a strong emotional response. ${ }^{28}$

Under the weight of evangelism, imperialism, and the legacy of phantasmagoria, the fragile walls between reality and fantasy could not always hold for the spectators. The very name of the showthe "magical" quality of the lantern as technological apparatus-illuminates the confusion between the paranormal and the real.

Twain personally spurned missionary work, calling it "the least excusable of the spiritual petty larceny industries." ${ }^{29}$ Yet, in spite of his disdain for spiritual petty larcenists, he took his cues from the missionaries' tactics to raise awareness about the crimes against humanity. With its collection of imagery spanning from the phantasmagoric to the documentary, King Leopold's Soliloquy would plumb this liminal space exposed in the magic lantern show. In doing so, Twain's pamphlet intimated to his audience that the cold documentary reality of Leopold's crimes surpassed the most nightmarish of supernatural horrors.

Whether in the form of writing, such as Williams' open letter, or imagery, such as the missionaries' magic lantern shows, both word and image conspired to systematically present evidence of collective violence. Certain reformers, such as Morel, had already juxtaposed written and visual testimony in weekly journals, such as the West African Mail, and in exposés, such as Morel's 1904 King Leopold's Rule in Africa, which included photographs of rubber-collection stations, Congolese amputees, and Western reformers like Casement. Twain's unique contribution to the cause was the pairing of word and image within the literary genre of the dramatic monologue. His protagonist follows in the footsteps of other monologists: like Shakespeare's Macbeth or the narrator of Robert Browning's 1842 poem "My Last Duchess," Leopold inevitably condemns himself. Through the rhetorical move of paralipsis, or the discussion of a topic only to deny it, Twain imprisons Leopold in his own language.

In the guise of this classical literary form, King Leopold's Soliloquy traffics in human rights rhetoric and imagery, enlisting a chorus of witnesses who condemn the systematic violence of Belgian colonialism. American and British missionaries, Congolese rubber collectors, European parliamentarians, and Western writers (including Conrad) take the virtual stand, testifying against a colonial tyrant. Ultimately, this heteroglossia, or variety of conflictual voices - Leopold's versus his enemies' - refracted in a single text, resists the very title of Twain's work. It is not as much a soliloquy as a noisy conversation. In fact, it is a shouting match between Leopold and his hemispheric army of sworn enemies. The text is a wolf, a human rights manifesto, disguised in the sheep's clothing of a satirical soliloquy from the mouth of a sadistic king.

But Twain knew that word alone was not enough; imagery was needed, too. Cultural critic Roland Barthes describes this ecosystem between image and text as "the totality of the information... carried by two different structures (one of which is linguistic)." 30 Twain consequently turned to sketches and drawings based on missionaries' journals and eyewitness testimony. He also enlisted images reproduced from the photographs taken by the British missionary Alice Harris, whose work had already begun to circulate in Morel's 1904 publication, King Leopold's Rule in Africa. By yoking together word and image in this way, Twain's text emulated a non-textual experience in the tradition of the magic lantern show, a multimedia theatrical phenomenon leveraged by social reformers such as Riis and the Harrises.

Whether in word or in image, the humanitarian movement of the Congo Free State amplified the voices of Westerner (predominantly white) men like Casement, Morel, and Twain over those of Western women and the Congolese people. While certain white Western women such as Alice Harris actively participated in the campaign, their roles were complicated: while they were not

\footnotetext{
${ }^{28}$ Sliwinski, The Childhood of Human Rights, 348.

${ }^{29}$ Hunt Hawkins, “Mark Twain's Involvement with the Congo Reform Movement: 'A Fury of Generous Indignation,"' New England Quarterly 51, no. 2 (1978), 171-172.

30 "Of the two structures, one is already familiar, that of language... while almost nothing is known about the other, that of the photograph." Roland Barthes, Image-Music-Text, trans. Stephen Heath (New York: Hill and Wang, 1978), 16. Barthes also discusses the differences between the denoted and the connoted messages of the photograph.
} 
completely silenced, they did not enjoy the privileges granted to many of their male counterparts. For example, from 1905 to 1910, Harris lectured prolifically on the Congo Free State, giving a minimum of 220 lectures in England alone, often without her husband. ${ }^{31}$ Yet, in the caption of what would become one of the CRA campaign's most well-known photographs - of a Congolese father named Nsala peering at the remains of his daughter, who has been killed and eaten by rubber sentries-Morel's King Leopold's Rule misattributes credit to Alice's husband, "Mr. John H. Harris." ${ }^{32}$ As Kevin Grant writes, though her camera captured the atrocity images, Harris "did not, initially, author the narrative that defined the significance of the photographs for the British public." ${ }^{33}$ As a white woman at the turn of the century, Alice Harris was both present and absent within the shaping of the CRA's story.

As Laura Wexler has argued, these nuanced shifts in power for white, middle-class, Western women photojournalists in the late 19th century were double-edged. No longer always sitting in front of the camera as they had in previous decades, "their shift from object to operator emboldened justifications of Anglo-Saxon aggression at the start of the American century." ${ }^{34}$ The Congolese people, on the other hand, often found themselves in directly in front of the cameras, their image framed by Westerners such as Alice Harris. On the whole, the CRA muffled Congolese voicesother than the testimonies, such as those woven into the narrative tapestry of Twain's King Leopold's Soliloquy, that were recorded and mediated by Western bystanders, often male missionaries. ${ }^{35} \mathrm{As}$ witnesses to or survivors of Leopold's collective colonial violence, these two groups - Western women and the Congolese survivors-usually remained either directly behind or in front of the camera. Far from Morel's headquarters in Liverpool, their voices were often stifled, and their names were often erased. ${ }^{36}$ Yet, paradoxically, though mute in many ways, they testified most loudly as witnesses to crimes against humanity.

In the arithmetic of collective violence, these images of atrocity may have been equal to the thousands of words with which they were paired. But in the end, even such documentary evidence-of arms without hands, feet without legs, and fathers without daughters-did not staunch the hemorrhaging of Congolese lives or compel Western governments to intervene quickly enough. In 1906, Twain resigned from the movement; increasingly pessimistic in his final years, he had become estranged from the American CRA and exasperated with the relatively slow pace of diplomatic change. ${ }^{37}$ By that time, several million Congolese lives had been lost to Leopold's violence. ${ }^{38}$ Despite Twain's eventual pessimism regarding the CRA (by 1907, his copy of Morel's exposé, Red Rubber, was "in constant use as a window prop"), his own pamphlet helped galvanize the American public's awareness and outrage. ${ }^{39}$ In December 1906 newspapers exposed the

\footnotetext{
${ }^{31}$ Pavlakis, British Humanitarianism, 119, 122.

${ }^{32}$ Grant speculates on the possible reasons for this photographic misattribution, including patriarchal gender roles within Western missionary structures at the turn of the century. See Grant, The Limits of Exposure, 74.

${ }^{33}$ Ibid., 74

${ }^{34}$ Laura Wexler, Tender Violence: Domestic Visions in an Age of U.S. Imperialism, New ed. (Chapel Hill: The University of North Carolina Press, 2000), 6. In her study of several "New Women" American photojournalists in the late 1890s and early 1900s (such as Frances Benjamin Johnson, Alice Austen, et al.), Wexler discusses how what she terms "the innocent eye," a representational practice afforded by "white domestic sentiment" enabled these women to occlude the violence, racism, and war within the colonies by framing these spaces as sites of peace. Wexler, Tender Violence, 6-7

${ }^{35}$ Here, it is important to keep in mind what Saidiya Hartman notes: how the power differential between interlocutors in such transcribed testimonials can occlude transcriptions with racism, historical revisionism, and factual error; drawing on the work of Gayatri Spivak, she writes, "there is no access to the subaltern consciousness outside dominant representations or elite documents." Saidiya Hartman, Scenes of Subjection: Terror, Slavery, and Self-Making in Nineteenth-Century America, $1^{\text {st }}$ ed. (New York: Oxford University Press, 1997), 10.

${ }^{36}$ For more on the imbrications of photography, race, colonialism, and the optical unconscious, see Shawn Michelle Smith and Sharon Sliwinski, eds., Photography and the Optical Unconscious (Durham: Duke University Press, 2017).

${ }^{37}$ Hawkins, Mark Twain's Involvement, 165.

${ }^{38}$ Twain's text accuses Leopold of being "the King with Ten Million Murders on his Soul." Twain, King Leopold's Soliloquy, 25; Historian Adam Hochschild also estimates that "during the Leopold period and its immediate aftermath the population of the territory dropped by approximately ten million people." He notes that Congolese scholar Ndaywel é Nziem has put the number near 13 million. Hochschild, King Leopold's Ghost, 233, 315.

${ }^{39}$ Hawkins, Mark Twain's Involvement, 172.
} 
revelations that American lawyer Henry Kowalsky, suborned by Leopold's agents, had not only accepted Belgian bribes but had also attempted to influence Congress through lobbying efforts. By the time the story was published, the American Senate and the public at large were familiar with the CRA's publicity campaign and, thus, were primed for indignation. In the wake of the Kowalsky scandal, widely publicized atrocity images - such as those photos of severed Congolese handsgave visual weight to newspaper headlines such as "Infamous Cruelties" and "U.S. Amazed at Crimes of Congo." ${ }^{40}$ If the Kowalsky revelations were a match, then the CRA and Twain's efforts were the kerosene, both elements contributing to the conflagration of American public uproar about Leopold's regime. In tandem, this public awareness and subsequent indignation set the stage for President Theodore Roosevelt's decision in late 1906 to officially condemn the Congo Free State ${ }^{41}$ As a result, historians consider King Leopold's Soliloquy a document that contributed to the catalyzing of American political reform that would ultimately oust the "blood-drenched king." 42

\section{The Blood-Drenched King}

As Barthes notes in Image - Music - Text, because of its inherent communication with written text, such as a caption, title, or article, a visual image such as a press photograph never stands in complete isolation. ${ }^{43}$ The images in King Leopold's Soliloquy illustrate this point. A drawing of Leopold atop a pyramid, flanked by throngs of marching skeletons, for example, resides in the realm of the phantasmagoric, nearly supernatural mode. A mountain of Congolese skulls scattered in a field lingers in a liminal register somewhere between abstraction and realism. A woodcut print of a bereft Congolese father, based directly on Alice Harris' already infamous photograph, is documentary in its realist depiction of collective violence. ${ }^{44}$ By relying on both documentary and abstract visual depiction, Twain hoped to telegraph to his readers the gravity of what Conrad's Kurtz had so famously called "the horror" of the Belgian Congo. Paired with their respective captions, these images illustrate how Leopold's crimes simultaneously stretch the very limits of the imagination and yet exist as documented fact.

In including different modes of visual imagery-both realist and abstract-each depicting a different scale and mode of genocidal carnage, Twain aimed to haunt his readers. Through the rhetoric of each image-the combination of the visual and linguistic structures such as captions - and the several appendices of official reports, eyewitness interviews, and parliamentary proceedings well outside the literary genre-Twain hoped to inspire a response that would lead to political intervention. According to Twain, the problem lay not in a lack of empathy (a slippery concept in itself) with the Congolese subjects, but in his European-American audience's disbelief in Leopold's crimes against humanity. In the soliloquy's final pages, the monarch reads aloud from an unnamed reformist publication. This particular swatch of text, made up by Twain, draws inspiration from rhetoric found in Morel's West African Mail, an object of Leopold's scorn. Here Twain, ventriloquized through Leopold, describes the collective Western public reluctance to confront the crimes of the king:

We see this awful king, this pitiless and blood-drenched king... and-well, it is a mystery, but we do not wish to look; for he is a king, and it hurts us, troubles us, by ancient and inherited instinct it shames us to see a king degraded to this aspect, and we shrink from

\footnotetext{
${ }^{40}$ Hochschild, King Leopold's Ghost, 248-249.

${ }^{41}$ On December 11, 1906, President Roosevelt wrote to the British Foreign Secretary, Sir Edward Grey, notifying him of a decision to official condemn the Congo Free State and describing being "moved by the deep interest shown by all classes of the American people in the amelioration of the conditions in the Congo State." Hawkins, Mark Twain's Involvement, 172-173.

${ }^{42}$ See Hawkins, Mark Twain's Involvement, 172-173; Joan Baum, “Mark Twain on the Congo," Mark Twain Journal 17, no. 2 (1974), 7.

${ }^{43}$ Barthes, Image-Music-Text, 16.

${ }^{44}$ Here, I am following the lead of visual historians such as Sliwinski who have identified this particular image of Nsala as a woodcut print based on Alice Harris' photograph. Sharon Sliwinski, Human Rights In Camera (Chicago: University of Chicago Press, 2011), 71. Also see Christina Twomey, Framing Atrocity, 59.
} 
hearing particulars of how it happened. We shudder and turn away when we come upon them in print [emphasis in original]. ${ }^{45}$

As writer of this fictitious reform pamphlet read aloud by Leopold, Twain employed the first person plural pronoun of "we" to include himself with his imagined Western readership. For Twain, "to see" the "pitiless and blood-drenched king" is not the same as "to look" at him. By this logic, "seeing" implies a passive disengagement. The active practice of "looking," on the other hand, would require a radical resistance to the "ancient and inherited instinct," a refusal to believe a king so "awful." In turn, such looking results in "shuddering," a physical reaction that encompasses an affective response (empathy, disgust, horror). This effervescent shuddering overpowers the spectator, compelling him to "turn away" when coming upon "the particulars of how it happened in print." Strikingly, this passage locates the horror of the situation not so much in Leopold's campaign of collective violence against the Congolese subjects as in the depravity of a Western ruler.

A true reckoning with Leopold's crimes, Twain's soliloquy suggests, requires the engagement of multiple senses. "We shrink," Twain writes in the soliloquy, "from hearing particulars of how it happened." Images, or objects at which one may look or see, are intertwined with sounds, or words that may be heard. For Twain, it is not so much a matter of believing, or activating the imagination, but looking at the evidence in front of one's eyes. Their relationship of looking and hearing, by extension, is chiastic: in regard to the implications of Leopold's crimes, one cannot be fully understood without the other. Alongside hearing, the act of looking - a refusal to avert one's eyes, an invitation to shudder - becomes a political act. In other words, to engage with Leopold's crimes requires a multi-sensorial looking, or, in the words of critic Fred Moten, a practice of "looking that cannot be sustained as unalloyed looking but must be accompanied by listening." 46 In this light, as Moten writes in his reading of Roland Barthes alongside the open-casket photo of Emmett Till and the sounds surrounding his 1955 death, "a lingering look at-aesthetic response to-the photograph manifests itself as political action." 47 Black feminist critic Tina Campt also emphasizes the importance of listening, but departs from Moten in terms of her specific attention to the frequencies of what she terms "quiet" photographs taken of the Black Diaspora; attentive to what she terms the "haptic encounter," her methodology attends to a "practice of looking beyond what we see and attuning our senses to the other affective frequencies which photographs register." 48 Taking inspiration from these scholars, if we as readers resist what Moten terms "occularcentrism" and listen to the words and sounds surrounding the imagery in King Leopold's Soliloquy, we may arrive one step closer to finding out what happens in the gulf between haunting and understanding. ${ }^{49}$ We must first return to Barthes' rhetoric of the image.

\section{Too Horribly Picturesque It Is}

From the outset, King Leopold's Soliloquy muddles genres, defiantly refusing to adhere to a single category. The text hopscotches from satirical soliloquy to eyewitness testimonials in the name of human rights, such as excerpts of reports from African American missionary W. H. Sheppard, who describes witnessing the roasting of eighty-one right hands over a fire during a visit to the Congo Free State in $1890 .^{50}$ In this vein, a single page in the text may suture together a rhetorical crazy

${ }^{45}$ Twain, King Leopold's Soliloquy, 41-42. In a dictation for his autobiography, Twain called the apocalyptic carnage of the Middle Ages, which he had lampooned in his 1889 satirical novel, A Connecticut Yankee in King Arthur's Court, "heaven itself" compared to the violence of the Belgian Congo. See Hawkins, "Mark Twain's Involvement with the Congo Reform Movement," 172.

${ }^{46}$ Fred Moten, In the Break: The Aesthetics of the Black Radical Tradition (Minneapolis: University of Minnesota Press, 2003), 200.

${ }^{47}$ Ibid., 210.

${ }^{48}$ Tina M. Campt, Listening to Images: An Exercise in Counterintuition, Reprint ed. (Durham: Duke University Press Books, 2017), 9.

${ }^{49}$ Fred Moten, “Black Mo'nin'," in Loss: The Politics of Mourning, ed. David L. Eng, David Kazanjian, and Judith Butler (Berkeley: University of California Press, 2002), 62-63.

${ }^{50}$ Twain, King Leopold's Soliloquy, 24. 
quilt-stage directions for the king, Leopold's own ravings, a missionary's diary entry - alongside an illustrative sketch of a heap of skulls and femurs, with a caption lifted from the diary of A.E. Scrivener, a British missionary: "Some bones which they had seen." On this same page, Scrivener concludes this passage with a verdict on the visual evidence, which "all went to prove the state of terrorism that exists and the virtual slavery in which the people are held." 51

Though Scrivener's description refers to bondage in the Congo Free State, the phrases "states of terrorism" and "virtual slavery" could also describe the status of many African Americans in Twain's own country. After all, in the early $20^{\text {th }}$-century United States, Jim Crow laws institutionalized economic enslavement-and ritualized lynchings perpetuated physical terror. The text as a whole, however, makes no explicit reference to these twinned, Transatlantic violences against black bodies. At his most direct (which isn't direct at all), Twain tacks on a "supplementary" appendix to condemn the U.S. government's complicity in formally recognizing Leopold's International Association of the Congo in $1884 . .^{52}$ (He does, however, enlist satirical censure through Leopold himself, who, using some fin-de-siècle slang, boasts, "I certainly did bunco a Yankee"53). Even though Twain had written extensively on the legacy of slavery in the United States, most famously in Adventures of Huckleberry Finn, his 1885 novel seems to exist in a parallel universe from his writings on Leopold. For all of its gestures toward awareness about crimes against humanity abroad, the 1905 soliloquy remains politically tone deaf to the racialized atrocities taking place in Twain's own backyard.

Yet alongside the acrobatics of language-exclamations, diaries, reports, poems, and paralipsis-in King Leopold's Soliloquy, there is the rhetoric of the image. Throughout the document, images transmit their own messages, a series of signs that reverberate with the written text. Take, for instance, a drawing that protrudes, midway through the text, onto a single page from the left margins. Its square borders force Leopold's words to sidestep a sketch of six Congolese who approach a man dressed in Western attire of a safari helmet. In the sketch, five children surround a Congolese woman: an infant sits in the crook of her arm, and the other four, dressed in white, huddle beside her. Two of the boys, kneeling in the left-hand corner of the sketch, each thrust out a right arm. The boy's hand-less arm points diagonally upward toward the white Western man, whose back is turned to the reader. The sketch literally fractures Leopold's soliloquy, demanding that the written words give way to the visual imagery. The seven figures stand on a slender caption that has been extracted from Leopold's script: "They go to them with their sorrows." 54 Here, the caption functions as what Barthes calls "anchorage," or "a means of an often subtle dispatching, it remote-controls him toward a meaning chosen in advance." ${ }^{\prime 5}$ In this case, the seven-word caption connects, or anchors, the image to a linguistic message: "They go to them with their sorrows." The word "sorrows" dispatches a meaning, transposing a narrative that hovers over the image. This is a scene of nonverbal testimony, in which the word "sorrows" resonates with the two children's arms without hands, thrust toward the man in the safari attire. In causing the reader to witness the eye-witnessing of the missionary, King Leopold's Soliloquy creates a mise-en-abîme, a story within a story, literally placing the reader into the abyss. If the missionaries can speak out as eyewitnesses, the text implies, then so too can the reader.

After the physical intrusion of the sketch, the text continues, unabated, for several pages. Here, the subsequent stage directions-once again, in italicized font-signal the splitting of genre, the approach of a generic borderline about to be crossed. The text transitions from satirical soliloquy to eyewitness report as stage directions guide Leopold's actions: "Takes up a pamphlet. Reads a passage from a report of a 'Journey made in July, August, and September, 1903, by Rev. A. E. Scrivener, a

\footnotetext{
${ }^{51}$ Ibid., 17.

${ }^{52}$ Ibid., 45-46. According to Hawkins, this mistaken claim that the U.S. had a legal connection to the Congo Free State (since the U.S. had never formally signed the 1885 Berlin Agreement) would haunt Twain, contributing to his eventual resignation from the CRA in 1906. See Hawkins, "Mark Twain's Involvement with the Congo Reform Movement," 165.

${ }^{53}$ Twain, King Leopold's Soliloquy, 7.

${ }^{54}$ Ibid., 14.

${ }^{55}$ Barthes, Image-Music-Text, 40.
} 
British missionary." In the following breath (and for the next couple of pages) Scrivener's testimony transcribes a nightmarish world of violence, famine, and terrorism: "Lying about on the grass, within a few yards of the house I was occupying, were numbers of human skulls, bones, and in some cases complete skeletons. I counted thirty-six skulls, and saw many sets of bones from which the skulls were missing. ${ }^{\prime 56} \mathrm{He}$ records the explanation of the collection of bones given by a Congolese man:

I called one of the men and asked the meaning of it. 'When the rubber palaver began,' said he, 'the soldiers shot so many we grew tired of burying, and very often we were not allowed to bury; and so just dragged the bodies out into the grass and left them.' But I had seen more than enough, and was sickened by the stories that came from men and women alike of the awful time they had passed through..$^{57}$

Scrivener makes a request of the man for words that may explain "the meaning" of the carnage before his eyes. Overwhelmed by his own vision, the missionary has "seen more than enough." Yet it is the "stories that came from men and women alike" as much as the sights that leave him "sickened." The spoken narratives of the Congolese survivors become virtual captions, words that contextualize the gruesome sights around the missionary. By pairing Scrivener's transcription of Congolese testimony with a sketch of skulls in the grass, Twain sutured together word and image. In providing the sketch of the evidence witnessed by Scrivener, King Leopold's Soliloquy activates its readers' imaginations, beginning to fill the visual landscape: a skeletal sketch of skeletons. Here, words and images conspire to force the audience to navigate the perilous gulf between haunting and understanding. Between the two, they must confront their imaginations. On the other side, Twain seems to hope, the readers would advocate political interventions.

It is worth dwelling for a moment on the meaning of "imagination" and its etymological kinship with imagery. The verb "imagine" means "to form a mental image of, picture to oneself (something not real or not present to the senses)." ${ }^{58}$ The post-classical Latin noun imago, meaning a representation of a likeness, bequeathed the verb imaginer to Middle French before migrating into English as "imagine." To imagine, therefore, requires the creation of a mental image, the building of a virtual universe that exists outside of one's own immediate environment. Barthes goes one step further; pointing out that the word image (from imago) is linked to the root imitari. This etymology, he continues, exposes a philosophical quandary about the relationship between word and image: "Thus we find ourselves immediately at the heart of the most important problem facing the semiology of images: can analogical representation (the 'copy') produce true systems of signs and not merely simple agglutinations of symbols?"59 Is, as Barthes wonders, the image "representation, which is to say ultimately resurrection"? King Leopold's Soliloquy suggests that Twain would have responded yes: to re-present Leopold's crimes to the world was to represent them. The tightrope of the hyphen-between re-presentation and representation-made all the difference in bridging worlds through words and images.

A reader's response to an early version of King Leopold's Soliloquy illuminates how words may kindle mental images, generating pictures of other worlds beyond the immediate senses. In early 1905, Twain read aloud excerpts of a draft to his secretary Isabel Lyon and his sister-in-law Mrs. Crane. On February 22, Lyon reflected in her diary on the horror elicited by Twain's writing:

It was yesterday that Mr. Clemens read King Leopold's Soliloquy to Mrs. Crane \& me. Breathless we sat \& were weak with emotion when he finished the bald truthful statements that rolled from Leopold's vicious lips. Horribly - too horribly picturesque it is, \& Mr.

\footnotetext{
${ }^{56}$ Twain, King Leopold's Soliloquy, 16.

${ }^{57}$ Ibid., 16-17.

${ }^{58}$ Oxford English Dictionary, s.v. “Imagine, V.," accessed July 20, 2017, http://www.oed.com.proxy.lib.duke.edu/view/ Entry/91651.

${ }^{59}$ Barthes, Image-Music-Text, 32.
} 
Clemens will cut out some of it-It's a pity too-but I suppose it would be too strong a diet for people and governments. ${ }^{60}$

For Lyon, listening to the words requires the envisioning of new worlds. The "bald truthful statements that rolled from Leopold's vicious lips" act as verbal brushstrokes, painting an imaginative portrait of a tyrant. Ventriloquized through Twain, Leopold's words generate the envisioning of something Lyon called "too horribly picturesque." The unsettling reality portrayed by Twain upends the normal rules of grammar; Lyon's inversion of adjective and noun ("too horribly picturesque it is"), or anastrophe, suggests a world, like her syntax, temporarily turned upside down. The cataclysmic pairing of the adverb "horribly" with the adjective "picturesque" teeters on the precipice of sublimity: a mix of terror and beauty - all from the safe vantage of a sitting-room canapé. Twain's narrative physically affects its two auditors, leaving Lyon and Crane "breathless and weak with emotion" - not far from the very "shuddering" described by Leopold in the soliloquy's final pages. With its haunting descriptions and eliciting of horror, King Leopold's Soliloquy veers into the realm of the phantasmagoric, taking away the breath of its audience. It was like a magic lantern show - only without the magic lantern.

The physical layout of this particular page mirrors the interdependence of image, text, and imagination in King Leopold's Soliloquy. By extracting a fragment of Scrivener's text ("some bones which they had seen"), the anchorage of Twain's caption dispatches meaning to the image of skulls and bones. Even if these sketched skulls, dragged and scattered in a Congolese field, nestled in the grasses, were drawn by hand, they were doubly seen-both by the Congolese and the British witnesses. The sketch, which occupies nearly a third of the page, foregrounds a single skull, resting beside a femur, partially occluded by the stalks of grass. As the skulls (there are at least 36 of them) recede into the background, shrinking in size, they become uncountable. Collective violence renders precision impossible. Image and text chafe against one another; the image literally rests on Scrivener's testimony, buttressed by the written word. Twain imbued the text with panoramic immediacy, as if voyeuristically placing the reader in Scrivener's position, squarely in his point of view. The reader, by implication, becomes an indirect eyewitness to the carnage, now fleshless, in the wake of massacre.

As Barthes delineates, each image telegraphs both a connotative and a denotative quality. Given the Shakespearean overtones of King Leopold's Soliloquy, it is hard not to think of the famous skull in Hamlet: poor Yorick's "infinite jest." Without context, stripped bare of the caption or the written word, the image, especially the foregrounded skull, may connote the seventeenth-century motif of memento mori ("remember that you will die"). Embedded within the written landscape, however, the skulls in Leopold's realm denote a calculated, collective violence far from the realm of Shakespeare's Danish cemetery. This violence is necropolitical, subjugating life to the power of death, banishing individuated meaning from each person's demise. Achille Mbembe writes of how, in the case of colonial massacres, "lifeless bodies are quickly reduced to the status of simple skeletons. Their morphology henceforth inscribes them in the register of undifferentiated generality: simple relics of an unburied pain, empty, meaningless, corporealities, strange deposits plunged into cruel stupor." ${ }^{61}$ Unlike Yorick, these skulls remain nameless, undifferentiated, unburied - united by violence and its aftermath. To paraphrase Twain's secretary, Ms. Lyon, “too horribly picturesque" it is.

\section{The Incorruptible Kodak}

Midway through the text, directly across from Leopold's script (in this case, his ravings against Roger Casement), an image-this time, a woodcut print reproduced from Alice Harris' photographoccupies an entire page (Figure 1) ${ }^{62}$ Here, the landscape is pastoral: a gentle stream transects the

\footnotetext{
${ }^{60}$ Hawkins, Mark Twain's Involvement, 155.

${ }^{61}$ Mbembe, Necropolitics, 35.

${ }^{62}$ Twain, King Leopold's Soliloquy, 18. Woodcut prints based on photographs dated back to the American Civil War photography of Alexander Gardiner and Timothy O'Brady, often resorted to because of the technological limitations of mass circulation of photographs. For more historical context about the reproduction of photographs as woodcuts
} 


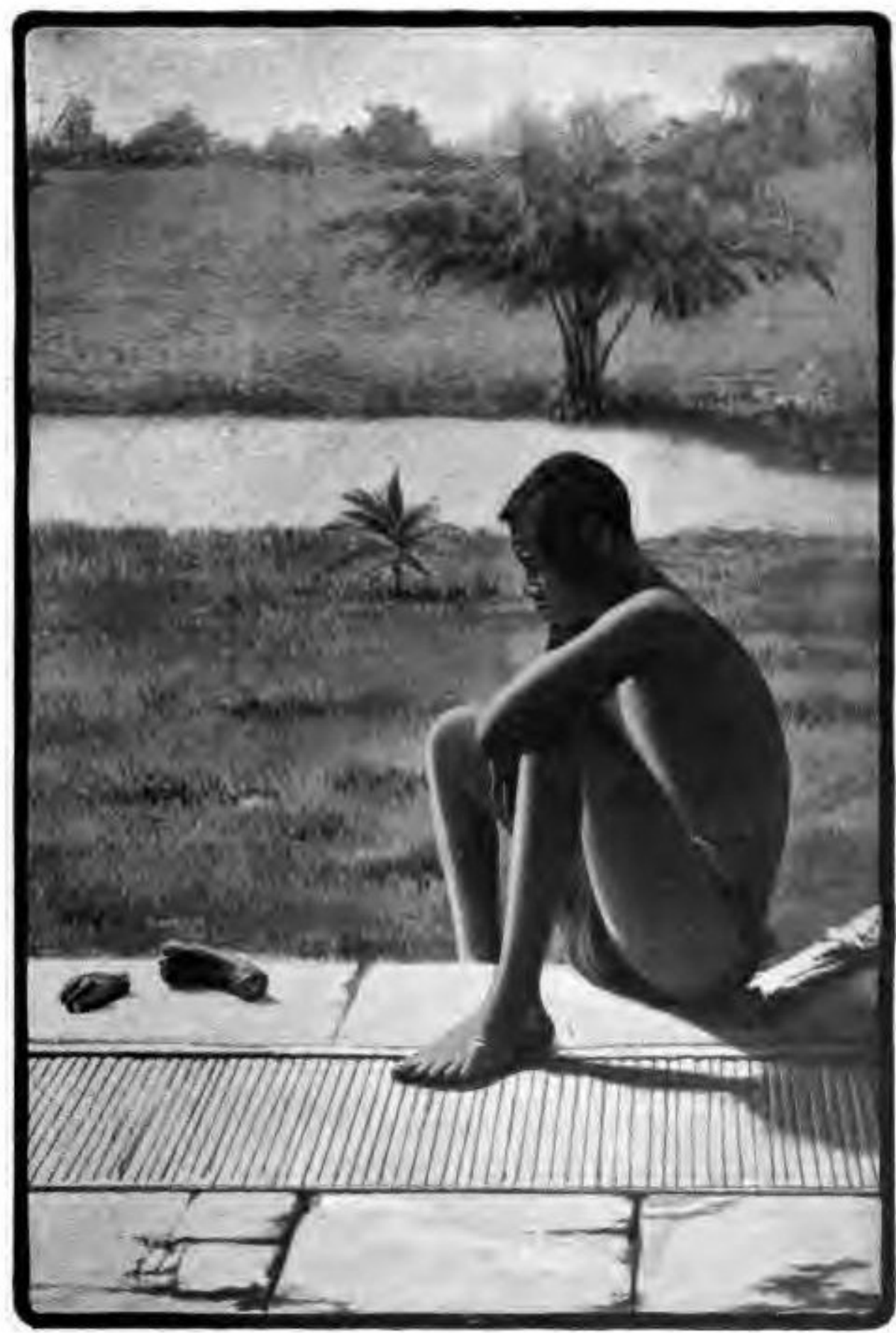

FOOT AND MAND OF CHILO DISMEMBERED BY SOLDIERS, BROUGHT TO MISSIONARIEB BY DAZED FATHER. FRON PHOTOGRAPH TAKEN AT BARINGA, CONGO STATE, MAY 15, 1904. SEE MEMORIAL TO CONORESS, JAMUARY, 1908

"Imagine the output of the whole vast State!"-Page 18.

Figure 1. 
scenery, and equatorial trees populate the top section of the background. A Congolese man sits on the ground, contemplatively, in profile, gazing at two small objects only an arm's length from his own body. An oblique triangular constellation comprises the man's torso, his head, and then the focus of his vision: the two small objects, nearly the same shade as the man's own complexion.

This image perches on two different captions, each in its own distinct font. Directly below the image, text written in all caps contextualizes the portrait. "FOOT AND HAND OF CHILD DISMEMBERED BY SOLDIERS," it begins. In conversation with the caption, the lines of these two objects violently, grotesquely come into focus as a foot and a hand-creating what Barthes calls the "studium" - or the aspect of the photo serving as a "kind of education" and recognition of the photographer's (in this case, Alice Harris') intentions: visual exposure of colonial carnage. ${ }^{63}$ This section of the caption, which provides anchorage to the image, grounding it in narrative context, identifies the perpetrators (the soldiers) and the victim (a child, of whose body we only see fragments - the hand and the foot). The child is both physically present-in a gruesome synecdoche, if the hand and foot can possibly stand in for the whole body-and also absent, without even a name.

The caption continues to contextualize the image: "Brought to Missionaries by Dazed Father." ${ }^{64}$ Here, it's important to consider how this caption speaks-or doesn't speak-to the image. It frames the identity of the man in the photo-he has become a "dazed father." Morel's previously mentioned 1904 King Leopold's Rule in Africa had included the same image and had provided further context, including the father's name (Nsala) as well as the daughter's (Boali). ${ }^{65}$ Yet Twain's pamphlet denies Nsala-unlike the British or American missionaries-his proper name. In a metonymic logic, this one man's tragedy, it seems, must stand in for all Congolese fathers, as a part for a whole. In this regard, the caption's rhetoric thematically rhymes with what literary critic Lynn Festa calls "sentimental humanitarianism." ${ }^{66}$ Evident in $18^{\text {th }}$-and 19th-century anti-slavery literature, sentimental humanitarianism can be found where "suffering masses are condensed into a single unthreatening figure." ${ }^{\prime 67}$ In this case, the father is speechless - both in terms of being "dazed," but also in terms of being denied any voice-or name-of his own in the text. Sontag elucidates how images, specifically those of nameless African victims, can perpetuate insidious narratives. She writes, "These sights carry a double message. They show a suffering that is outrageous, unjust, and should be repaired." Yet, "they confirm that this is the type of thing which happens in that place." 68

In keeping with Sontag's attention to such contradiction, while there are no details of the name of "the dazed father," the caption does provide a nearly surgical precision in terms of the time and place: "From Photograph take at Baringa, Congo State, May 15, 1904." ${ }^{69}$ The caption telegraphs a message to the reader: the woodcut print-is only a single preposition away from an actual photograph, taken at a single moment in time. Thus, the image walks a tightrope between imagined reproduction and visual evidence. Like the text as a whole, it resides in a liminal space between the real and the (sur)real. Later in the text, after studying what Twain's stage directions call "some photographs of mutilated Negroes," Leopold rages against "the incorruptible kodak...

\footnotetext{
in the 19th-century United States, see Bob Zeller, The Civil War in Depth: History in 3-D, Book and Access ed. (San Francisco: Chronicle Books, 1997). African American social reformer Ida B. Wells-Barnett also enlisted the woodcutbased on a photograph of the 1893 lynching of C. J. Miller in Bardwell, Kentucky -in her 1895 publication The Red Record. See Ida B. Wells-Barnett, The Red Record: Tabulated Statistics and Alleged Causes of Lynching in the United States (1895), chap. 4., https://www.gutenberg.org/files/14977/14977-h/14977-h.htm.

${ }^{63}$ Roland Barthes, Camera Lucida: Reflections on Photography, trans. Richard Howard, Reprint ed. (New York: Hill and Wang, 2010), 28

64 Twain, King Leopold's Soliloquy, 18.

${ }^{65}$ Edmund Dene Morel, King Leopold's Rule in Africa (London: W. Heinemann, 1904), 444.

${ }^{66}$ Lynn Festa, "Humanity without Feathers," Humanity: An International Journal of Human Rights, Humanitarianism, and Development 1, no. 1 (2010), 16, accessed July 21, 2017, doi: https://doi.org/10.1353/hum.2010.0007.

${ }^{68}$ Sontag, Regarding the Pain of Others, 71.

${ }^{69}$ Twain, King Leopold's Soliloquy, 19-20.
}

${ }^{67}$ Ibid., 6. 
the only witness I couldn't bribe. "70 Here, Twain underscores the difference between the Kodak, a machine, which seemingly cannot lie, and humans, all to susceptible to bribes. Yet, at the same time, this logic anthropomorphizes the Kodak by endowing it with the humanlike qualities of an "incorruptible witness." By metonymizing the camera-making the machine stand in for the human who actually frames and shoots the picture-Twain, through Leopold, constructs the "incorruptible kodak" as the ultimate witness, as if free of human influence and immune from corruption.

But the camera as eyewitness was not exactly "incorruptible." To the contrary, as many scholars have shown, this technology was often leveraged as a tool of empire, colonialism, and white supremacy. ${ }^{71}$ As Cole reminds us, the camera, especially when pointed at the racial Other in the name of ethnographic "fact," often inflicts its own insidious violence: "Photography is particularly treacherous when it comes to righting wrongs, because it is so good at recording appearances." 72 Furthermore, as Dean Pavlakis has pointed out, Alice Harris staged several of her photographs as re-enactments of atrocity crimes for "dramatic effect;" for example, the photograph of Nsala was "a carefully arranged tableau of onlookers, grieving father, and severed hand and foot" - a fact that would soon be seized upon to discredit the CRA by Leopold's propagandists (who staged their own photos - an irony apparently lost on the king's Brussels-based publicists). ${ }^{73}$ Many readers of Twain's text would have recognized these recorded appearances such as the one of the dazed father from the photographic magic lantern shows, those spaces in which the real and the phantasmagoric blurred under the Western Christian gaze.

\section{Fresh Skeletons Enough}

As early as the soliloquy's first pages, Twain relied on both documentary and abstract, realist and supernatural, imagery to tell his whole story. Opposite the soliloquy's title page, an image of Leopold looms, as if menacing even the typeface listing the author, publisher, and edition. In the background, Leopold stands atop a pyramid, hoisting a flag in his right hand and what appears to be a scepter in his left. Throngs of headless skeletons, linked by their arms, radiate from the base of the pyramid. In the drawing's foreground, lightning bolts cast their spindly shadows onto the grasslands. Unlike the more documentary drawings, this image resides firmly in the abstract realm: there may be headless skeletons in the Congo Free State, but they cannot rise from the dead and form chains around the despot. In terms of symbolism, in Leopold's body politic, he is the only one with a head - the Congolese skeletons denied of even their own skulls, and, by extension, their humanity. Like photographs projected in the magic lantern shows, the drawing lingers in the phantasmagoric mode. By turning to the fantastical, Twain aimed to show his readers that the reality in the Belgian Congo was simultaneously based in documentary evidence-and yet it surpassed the imaginative boundaries of a reader's most obscene visions. The collective violence lurked in broad daylight, under the "unbribable" lens of the Kodak, but also after dark, in the territory of nightmares.

The image rests upon a slender caption - "A memorial for the perpetuation of my name. Page 27." - which signals the interdependency of image and text. ${ }^{74}$ The reader must turn to page 27 , nearly halfway through the tract, in order to find context for the caption. The drawing shares a

\footnotetext{
${ }^{70}$ Ibid., 39-40.

${ }^{71}$ See Sliwinski, Human Rights In Camera; John Peffer, "Snap of the Whip/ Crossroads of Shame: Flogging, Photography, and the Representation of Atrocity in the Congo Reform Campaign," Visual Anthropology Review 24, no. 1 (2008), 55-77; Wexler, Tender Violence; Fehrenbach and Rodogno, eds., Humanitarian Photography: A History.

${ }^{72}$ Teju Cole, "Getting Others Right," New York Times Magazine, June 13, 2017, accessed July 23, 2017, https://www.nytimes. com/2017/06/13/magazine/getting-others-right.html.

${ }^{73}$ Pavlakis, British Humanitarianism and the Congo Reform Movement, 1896-1913, 185-186. It is important to keep in mind that, as Peffer points out, in spite of being "staged," the veracity of the colonial violence surrounding the photographs such as those taken by Alice Harris is not at issue. See John Peffer, Snap of the Whip, 67. The act of staging photos, especially in the shadow of collective violence such as war, was a practice dating back to the mid-19 $9^{\text {th }}$ century. Susan Sontag describes the staging of photographs in the Crimean War, and Franny Nudelman glosses the practice during the American Civil War. See Sontag, Regarding the Pain of Others, chap. 3; Franny Nudelman, John Brown's Body: Slavery, Violence, \& the Culture of War (Chapel Hill: The University of North Carolina Press, 2004), chap. 4.

${ }^{74}$ Twain, King Leopold's Soliloquy, 2.
} 
synapse with the caption, which then directs the reader to the middle of one of Leopold's rants: in this case, a description of a "memorial for the perpetuation of my name" designed by a "madman" who is "full of vindictive enthusiasm over his strange project." ${ }^{75}$ As the monarch disdainfully describes the memorial, the details bring the drawing into sharp focus: a mausoleum, modeled on the Great Pyramid of Cheops, will be built out of 15,000 skulls and skeletons, with a base of 13 acres and 451 feet above the ground. Robed and crowned, Leopold holds "his 'pirate flag"' in one hand and his "butcher-knife and pendant handcuffs" in the other. ${ }^{76}$ Text spills onto the following page as the tract of land has been "depopulated," its former denizens transformed into "the spirits of the starved and murdered dead... [who] voice their laments forever in the whispers of the wandering winds." ${ }^{\prime 77}$ Leopold resides not over a colony, but a necropolis.

Examined side by side, an arithmetic of human suffering emerges from the image and the text. A macabre calculus infiltrates Leopold's description of the memorial. Each "osseous fence," he explains, consists of "200,000 skeletons on a side, which is 400,000 to each avenue." 78 In trying to communicate the scale of the violence in the Congo Free State, Twain turned to United States geography, a narrative strategy indicative of an appeal to his American readership. Twain ventriloquized a revealing analogy through Leopold: "It is remarked with satisfaction that it aggregates three or four thousand miles (single-ranked) of skeletons - 15,000,000 all told - would stretch across America from New York to San Francisco." ${ }^{79}$ Veering into bureaucratic rhetoric, king prognosticates an "output of 500,000 corpses a year when my plant is running full time" before projecting "fresh skeletons enough to continue the transcontinental file... a thousand miles into the Pacific." 80 In tandem, the drawing and the paragraph enable Twain to create a cartography of collective violence and to better communicate the scale of Leopold's carnage to his American readership. By providing his readers with a geographical scope, however U.S.-centric, Twain provided them the imaginative longitudes and latitudes of scenes of crimes against humanity.

\section{The Terrible Story, Brought Thoroughly Home}

At the home of a New Hampshire neighbor in autumn of 1905, mere months after the publication of King Leopold's Soliloquy, Twain met a fellow reformist who shared his growing exasperation with the tactics of the CRA. Unlike Twain, Dihdwo Twe, a Liberian student, had actually visited the Congo Free State prior to studying at Cushing Academy in Ashburnham, Massachusetts. In a letter dated February 8, 1906, Twe confided in Twain his frustration with the reform movement's reliance on printed materials to reach its intended audience:

...To speak the truth, I am dissatisfied with the method of the 'Congo Reform Association'; they are trying to influence this great country by distribution of printed circulars. This will take too much money, too long time, and besides the result will always remain uncertain. ${ }^{81}$

Twe's letter evinces skepticism about the CRA's faith in "printed circulars" - such as Twain's own King Leopold's Soliloquy - to inaugurate political reform. The Liberian student's concerns were rooted in finances ("too much money") and temporality ("too long time"). But most of all, he pinpointed his doubts in something that haunts literary efforts to sway human rights to this day - the lack of a quantifiable barometer with which to measure the effects of the literature: "the result will always remain uncertain." ${ }^{82}$ Of course, readers like Ms. Lyon might recoil from the nightmarish imagery. But after the shuddering, as Twain's own Leopold predicted, would she and

\footnotetext{
${ }^{75}$ Ibid., 27.

${ }^{76}$ Ibid., 27.

${ }^{77}$ Ibid., 28.

${ }^{78}$ Ibid., 28.

${ }^{79}$ Ibid.

${ }^{80}$ Ibid., 28-29.

${ }^{81}$ Hawkins, Mark Twain's Involvement, 170-71.

${ }^{82}$ Ibid., 171.
} 
her fellow readers turn away? For the Liberian reformer, printed materials - the written words, the printed photographs - were simply not enough.

If Twain's pamphlet had failed to bring the Americans to the Congo Free State, then Twe wanted to bring the corporeality of the Congo Free State to the Americans. It turns out that Twe had his own scheme in mind: a proposal to bring two or three Congolese children with mutilated limbs to the United States. The CRA, approximately $\$ 5,000$ in debt (in spite of the soliloquy's proceeds, donated by Twain), refused. ${ }^{83}$ According to a note penned by Lyon, written on the back of Twe's letter, the American author endorsed the idea, deeming it "excellent, but he doubts if it is really worthwhile to continue to the agitation in America with the idea of getting help from our government." ${ }^{84}$ The volition of the Congolese children, it seems, was never in question for either Twe or for Twain.

While Twe's proposal never came to fruition, his idea brings to light the political limits and possibilities of the paired printed word and image. Let us consider Barthes' claim that images, such as photographs, pin their subjects to a single moment, "anesthetized and fastened down, like butterflies." ${ }^{15}$ If an image tethers its subject to a single instance in the past, then the presence of a human being - a survivor of Leopold's violence brought over to America, for instance-would shift temporality. No longer fastened down on the page, the Congolese survivor would breathe, move, and inhabit the present tense, no longer captive on the page, and no longer surrounded by words of others. Twe's idea rests on the faith in naked eye-witnessing: if only the American people could see the evidence of Leopold's carnage not in a photograph or a drawing, but in real life, bridging the gulf between page and reader, witnessing without the intermediary of the Kodak. By this logic, if the American people could not only read, but also hear the testimony of the Congolese children - translated both literally and figuratively into a language accessible to the audiencethen they would be unable to turn away. By eschewing adults as representatives of Leopold's violence in his humanitarian appeal, the Liberian activist relied on the visual registers of children as what anthropologist Liisa Malkki has called "embodiments of a basic human goodness" and as sufferers. ${ }^{86}$ Twe wanted to correct what Sir Arthur Conan Doyle would later point to as the failure of the CRA: poor storytelling ("the terrible story has not been brought thoroughly home to the people $\left.{ }^{\prime \prime}\right) \cdot{ }^{87}$ If the story had not been thoroughly brought home to the American people, then Twe would turn to the interpellating act of the physical presence of human beings. According to this logic, the Congolese children would be made to literally stand in for the story-one that had to be told even better than before.

By eliminating the camera, Twe would bring the American audiences one step closer to believing the crime with their own eyes. Twe assumed that belief of this crime's existence-what George Washington Williams had in 1890 called a "crime against humanity" and what Raphael Lemkin would later list as an example of genocide-would leave its witnesses with no choice but to act. ${ }^{88}$ The preposition shifts, and the game changes: Twe aimed for Americans to no longer linger in the realm between word and image, but beyond word and image. According to this idealist logic, having survived the harrowing journey of the imagination, they would emerge on the other side, ready to slay the man whom Twain called a "bloody monster whose mate is not findable in human history anywhere." ${ }^{\prime 9}$ These limbless children were never brought from Africa to America as evidence of Leopold's murderous campaign. Meanwhile, in Brussels, the monster and his publicists were preparing to strike back against Twain - not only with words, but also with images.

\footnotetext{
${ }^{83}$ Ibid.

${ }^{84}$ Ibid.

${ }^{85}$ Barthes, Camera Lucida, 57.

${ }^{86}$ Liisa Malkki, "Children, Humanity, and the Infantilization of Peace," in In the Name of Humanity: The Government of Threat and Care, ed. Ilana Feldman and Miriam Ticktin (Durham: Duke University Press, 2010), 60.

${ }^{87}$ Doyle, The Crime of the Congo, vii.

${ }^{88}$ Adam Hochschild, King Leopold's Ghost: A Story of Greed, Terror, and Heroism in Colonial Africa, First Mariner Books ed. (Boston: Houghton Mifflin, 1999), 111-112. See also Dean Pavlakis, British Humanitarianism and the Congo Reform Movement, 1896-1913 (New York: Routledge, 2016), 179.

${ }^{89}$ Hawkins, Mark Twain's Involvement, 172.
} 


\section{Answering Twain}

Though Twain and Twe may have despaired of the ability of printed materials to affect quantifiable political change, evidence suggests otherwise: Twain's salvo of the soliloquy prompted a counterattack from Leopold's propaganda machine. In 1907, a Brussels-based publishing house issued An Answer to Mark Twain, a 47-page tract written in English, presumably aimed at the American and British readers of King Leopold's Soliloquy. While the opening and closing pages of An Answer rely on language - several paragraphs accuse the American author of "an infamous libel" against the Congo Free State-the majority of the document places its faith in photographic evidence to contradict Twain's claims.

The Belgian propaganda participates in an irrational game of mixing and matching word and image: for every accusation of violence in Twain's soliloquy, An Answer responds with a pastoral photograph. Specifically, the tract takes aim at the reliance on illustrations in the reform efforts of Morel, who, in asking Twain to pen an attack on Leopold, "knew perfectly well that the soliloquy could not meet with success unless it was illustrated by the usual drawing of alleged acts of cruelty which had been promenaded all over England for years in the West African Mail." 90 Explanatory paragraphs bookend the middle section of $A n$ Answer, which follows a pattern: each page juxtaposes Twain's words, pastoral photographs of the Congo Free State, and captions of enthusiastic Western bystanders. The featured images include the following subjects: (a) landscapes, usually grasslands, emptied of humans, (b) infrastructure projects built with Congolese labor, such as railroads and bridges, and (c) medical clinics, technical schools, or churches, in which white men oversee what the Belgians term Congolese "progress." The visual scaffolding belies the tract's trust in its imagery to demolish the factual claims of Twain's language. In its Belgian creators' absurd calculus, the pastoral nature of the images could outweigh the American author's excoriating sentences, as if the existence of able-bodied Congolese people in selected photos precluded the occurrence of sadistic mutilation and systematic massacre occurring outside of the aperture's purview.

Somewhat ironically, both Twain and Leopold's publicists (the Bulens Brothers of Brussels) relied on the same strategy: faith that imagery - bolstered by written captions - would annihilate the other side's narrative. In this particular war of stories told by Western men about the Congo Free State, images were cannon fodder, and words the match to ignite the salvos against the other side. For example, a quotation plucked from King Leopold's Soliloquy marches across pages 20 and 21 of An Answer to Mark Twain: "The Congo State is wiping a nation of friendless creatures out of existence." 91 A series of four photographs, two on each page, depicts Belgian physicians in the proximity of Congolese subjects ("Doctor attending patients"), ostensibly tending to patients outside of thatched huts or brick buildings. ${ }^{92}$ These four images, plus the captions detailing the scientific inquiry into "tropical diseases," serve as a direct rebuke to Twain's quotation.

Yet the piece de resistance of the propagandist tract was its back cover: a case of fearful symmetry. In this visual sleight-of-hand, two nearly identical photos depict two Congolese women who sit outside a thatched dwelling, shaping pots. Beneath the first photo, a caption reads, "Potters at Work in the Congo." ${ }^{\prime 93}$ In the second photo, Belgian legerdemain has swapped one type of object for another: the handicrafts are no longer pots, but skulls. In reference to E.D. Morel's headquarters, the caption reads, "The Same Photo at Liverpool."94 Through this doctoring of photographs, this technological abracadabra, the pamphlet implicitly accuses the CRA of hyperbole. In doing so, it erases the colonial erasure of humans left outside the camera's frame.

\footnotetext{
${ }^{90}$ A. Bulens and G. Bulens, eds., An Answer to Mark Twain (Brussels: Bulens Brothers,1907), 41.

${ }^{91}$ Ibid., 20-21.

${ }^{92}$ Ibid., 22. Read retrospectively, the images of medical experimentation eerily resonate with the colonial campaigns of collective violence elsewhere on the continent: the German massacres of the Herero peoples in German South West Africa from 1904 to 1907, during which certain prototypes of medical experiments were first tested by Eugen Fischer, later to be taught to Nazi physicians and used during the Holocaust. Mahmood Mamdani, When Victims Become Killers: Colonialism, Nativism, and Genocide in Rwanda (Princeton: Princeton University Press, 2001), 12.

${ }^{93}$ Bulens and Bulens, An Answer to Mark Twain, 48.

${ }^{94}$ Ibid.
} 


\section{History that Rhymes}

I have argued herein that the relation (or dissonance) of visual imagery to written text in this relatively unknown and understudied work by Twain yields vital implications for the field of genocide studies. King Leopold's Soliloquy bequeaths two key lessons for scholars of genocide and collective violence. First, literary texts deserve fuller attention within the discipline. A close reading of King Leopold's Soliloquy reveals both the political possibilities and limitations in the chasm between image and written narrative, haunting and understanding, in the portrayal of collective violence with goals of political interventions. At the crossroads between documentary and abstract depictions of collective violence, the eclectic variety of images in King Leopold's Soliloquy raises questions about fact, testimony, and witnessing in the realm of human rights and collective violence. Following in the lineage of the phantasmagoric magic lantern shows, Twain's text puts forth an implicit claim: that documentary realism - such as the image of the nameless father staring at the childless limbs - is, in a way, more nightmarish than a fantastical, abstract drawing of Leopold, flanked by headless skeletons. The study of a literary text such as King Leopold's Soliloquy and the responses to its circulation, such as readers' reactions or Leopold's propagandist tract, An Answer, illuminates both the possibilities and the limits of literature in instrumentalizing visual imagery to catalyze political interventions in collective violence.

Like the audiences of the phantasmagoric magic lantern shows, Twain's readers constructed a virtual landscape of the "horribly picturesque," their imaginations activated by both word and image. Still, as Twe pointed out to Twain, the political results of such reactions were nebulous - did American readers, as Twain's Leopold predict, simply "shudder and turn away?" Could literature move masses of readers to lobby for reform? As writer Zadie Smith has observed, without legal interventions, literature alone-and the empathy that it may inaugurate-is not always enough: "You need to protect the weak, ring-fence them, with something far stronger than empathy." similar vein, nearing the end of his life, Twain considered his reform work a failure, lamenting that, unlike Morel, his own "literary interests" made him "not a bee, but a lightning bug." ${ }^{16}$ Yet even as a self-proclaimed "lightning bug," he shed enough light on Leopold's necropolitical crimes - the mutilations and the massacres - to rouse a reaction from the monarch's own propaganda machine.

The resulting cataclysm of literary word and image initiated imaginative possibilities with political imperatives. Only weeks after Twain's resignation from the CRA, a letter from a reader, one Mrs. Howland, briefly rekindled his faith in his own literary efforts. Ms. Lyon recounted how, after Howland's "tribute to the power of the pamphlet she wrote-'Money have I none, but I'll work like 'Hell' to help the cause.' Her zeal moved Mr. Clemens almost to tears. He shouted with joy \& then read it all over again-\& said he'd 'take that letter to Washington next week."'97 Later that year, Theodore Roosevelt, with whom Twain had met several times to advocate for reform in the Congo Free State, reached out to Britain to put diplomatic pressure on Belgium; in 1908, Belgium annexed the colony, removing it from the hands of Leopold, who ordered all archives of the Congo Free State destroyed. Yet, in 1909, after Sir Arthur Conan Doyle had appealed via letter to the American author to return to the movement, Twain excoriated the apathy of so-called Christians in his written response:

It seems curious that for about thirty years Leopold \& the Belgians have been daily and nightly committing upon the helpless Congo natives all the hundred kinds of atrocious crimes known to the heathen savage \& the pious inquisitor without rousing Christendom to a fury of generous indignation. ${ }^{98}$

To know, it seems, was not necessarily to be roused.

\footnotetext{
${ }^{95}$ Cressida Leyshon, "This Week in Fiction: Zadie Smith," The New Yorker, February 3, 2013, accessed July 20, 2017, http:// www.newyorker.com/books/page-turner/this-week-in-fiction-zadie-smith-2.

${ }^{96}$ Robert Wuliger, "Mark Twain on King Leopold's Soliloquy," American Literature 25, no. 2 (1953), 237.

${ }^{97}$ Hawkins, Mark Twain's Involvement, 168.

${ }^{98}$ Ibid., 175.
} 
Literature invites the depiction of current conditions and the envisioning of new possibilities with a latitude denied to other disciplines. By wandering into the fantastical, the real, or the phantasmagoric, zigzagging across genre, mode, and symbol, it offers something that no other discipline can: a space in which to radically question the very nature of storytelling itself. In the war of stories, Twain and Leopold were fighting in hand-to-hand combat. Was Leopold a humanitarian or a monster? By re-presenting visual imagery of Leopold's collective violence, Twain enlisted literature to in his attempt to represent the atrocities taking place across the Atlantic. And that's precisely why this chimerical work of literature - part satire, part manifesto, and part soliloquydeserves our attention as scholars of genocide.

King Leopold's Soliloquy also imparts a second lesson: it underscores the importance of broadening our time and space continuum in contemplating instances of genocide. In one regard, we should resist Lemkin's disciplining of his own discipline: the field of genocide studies would do well to make more room for scholars of the humanities in its anthologies. Yet, on the other hand, we would benefit from a return to Lemkin's own unfinished multi-volume history of genocide, which includes the Belgian Congo and German South West Africa (now known as Namibia), among others. Lemkin's neologism was, after all, a retrospective label, naming crimes that preceded the very term that would come to describe them. In this spirit, we would do well to consider not only the Holocaust and the genocides that came afterwards - Indonesia, Cambodia, Rwanda - but those that came before it, such as the settler genocides in German South West Africa and the United States. We should see Lemkin not only as a Cassandra, predicting the crimes of the future, but also as an Orpheus, looking backwards over his shoulder. These interlocking instances can help us understand the kinship between word and image - and haunting and understanding - across space and time, including in Twain's native land.

\section{Kin to the King}

In 1905, when Mark Twain enlisted imagery and literature to censure the colonial atrocities occurring a world away in the Belgian Congo, it was at the zenith of American imperialism and racial consolidations promoting Anglo-Saxon supremacy at home. That same year witnessed the publication of Thomas Dixon's novel The Clansman (adapted ten years later as the film The Birth of a Nation). Across the American South, white citizens, equipped with cameras, documented the spectacle of the ritualized lynchings of African American citizens. Anticipating the organized terror of what would be known as the second wave of the Klan (considered by many to begin in 1915 after the release of Griffith's film), white spectators scrawled captions such as "Let the White Supreme Forever Be" beside these gruesome photographs. ${ }^{99}$ Perpetrators and bystanders alike mailed these snapshots of collective violence as postcards, which crisscrossed the continent under the auspices of the U.S. Postal Service. ${ }^{100}$ Ironically, this point was made by none other than the Belgian writers of An Answer, who observed that the Twain's "sympathy is exclusively extended to the Congo natives. He is not in the least interested in a better understanding between blacks and whites in the United - States." ${ }^{101}$ While deeply attuned to issues of international human rights, the 1905 soliloquy is tone deaf to its own intranational violence.

Walter Benjamin once wrote, "There is no document of civilization that is not at the same time a document of barbarism."102 For all of Twain's appeal to human rights, political reform, and his readers' empathy, there is - to quote Hamlet - a "rub": a narrative hypocrisy, a willed blindness to the necropolitical violence within America's own borders - the very violence documented by Ida B. Wells and anti-lynching activists in the United States. Decades later, African American leaders

\footnotetext{
${ }^{99}$ Patricia Bernstein, The First Waco Horror: The Lynching of Jesse Washington and the Rise of the NAACP, New (College Station: Texas A\&M University Press, 2006), 54.

${ }^{100}$ Due to the mass influx of lynching photographs as postcards, in 1908 the U.S. Postmaster banned the practice by adding section 3893 to the Comstock Law, thus expanding the meaning of "indecent" material to include those that might "incite arson, murder, or assassination." See Linda Kim, "A Law of Unintended Consequences: United States Postal Censorship of Lynching Photographs," Visual Resources 28, no. 2 (2012), 174.

${ }^{101}$ Bulens and Bulens, An Answer to Mark Twain, 7.

${ }^{102}$ Walter Benjamin, Illuminations, ed. Hannah Arendt, trans. Harry Zohn (New York: Schocken Books, 1968$), 256$.
} 
William L. Patterson, Paul Robeson, and the Civil Rights Congress would draw upon Lemkin's own language to argue that the newly named crime of genocide had taken place on American soil. In their 1951 manifesto, We Charge Genocide, the CRC appealed to the United Nations to charge the American government with crime of genocide against the black population within the United States. ${ }^{103}$ Lemkin, however, publicly opposed the CRC's use of the term, as indicated in a special report that ran in the New York Times the same year. ${ }^{104}$ In private correspondence, Lemkin wrote to Patterson that "the provisions of the Genocide Convention bore no relations to the U.S. Government or its position vis-à-vis Black citizens." ${ }^{105}$ Yet historical facts erode the foundations of Lemkin's logic: after all, in the architecture of the Third Reich, the Nazi party had looked to none other than the eugenics practices and Jim Crow laws in the United States for inspiration. ${ }^{106}$ The legacy of the CRC's petition continues to this day, as evident in the name of the grassroots social justice organization, We Charge Genocide. ${ }^{107}$

As documented in the pages of King Leopold's Soliloquy, on May 15, 1904, a "dazed father" gazed at his daughter's hand and foot in Baringa, Congo Free State. Meanwhile, on the very same day, across the Atlantic, in the town of Appling, Georgia, a white mob lynched John Cummings, an African American citizen. ${ }^{108}$ Though these white American spectators didn't fear the Kodak -in fact, they embraced it-time and time again they proved themselves kin to King Leopold, thirsty for blood and hungry for violence. ${ }^{109}$ To borrow an adage commonly misattributed to none other than Mark Twain, while history may not have repeated itself, it rhymed. ${ }^{110}$ Whether in Baringa or in Appling, the Kodak - a mute witness that resisted bribery - testified to crimes against humanity. If we look closely enough across the centuries, we can listen to history, and we can even hear it rhyme.

\section{Bibliography}

Allen, James, Hilton Als, John Lewis, and Leon F. Litwack. Without Sanctuary: Lynching Photography in America. 10th ed. Santa Fe: Twin Palms Publishers, 2000.

Apel, Dora, and Shawn Michelle Smith. Lynching Photographs. Berkeley: University of California Press, 2007.

Barthes, Roland. Camera Lucida: Reflections on Photography. Translated by Richard Howard. New York: Hill and Wang, 1981.

--------. Image-Music-Text. Translated by Stephen Heath. New York: Hill and Wang, 1978.

Baum, Joan. "Mark Twain on the Congo." Mark Twain Journal 17, no. 2 (1974), 7-9.

${ }^{103}$ William L. Patterson, ed. We Charge Genocide: The Crime of Government Against the Negro People (New York: International Publishers, 1970).

104 “U.S. Accused in U.N. of Negro Genocide," The New York Times, December 18, 1951, 13.

${ }^{105}$ William L. Patterson, The Man Who Cried Genocide: An Autobiography (New York: International Publishers, 1971), 179.

${ }^{106}$ For example, the 1927 U.S. Supreme Court case Buck v. Bell, which legitimized eugenic sterilization, was cited in the Nuremberg trials as a legal precedent for the Nuremberg Laws. Recent scholarship on the influence of American racist practices on Nazi Germany includes James Q. Whitman, Hitler's American Model: The United States and the Making of Nazi Race Law (Princeton: Princeton University Press, 2017); Adam Cohen, Imbeciles: The Supreme Court, American Eugenics, and the Sterilization of Carrie Buck, Reprint ed. (New York: Penguin Books, 2017).NJ: Princeton University Press, 2017

${ }^{107}$ For further discussion, see Dylan Rodríguez, “Inhabiting the Impasse Racial/Racial-Colonial Power, Genocide Poetics, and the Logic of Evisceration," Social Text 33, no. 3 (2015), 19-44.

${ }^{108}$ Ralph Ginzburg, 100 Years of Lynchings (Baltimore: Black Classic Press, 1962), 258.

${ }^{109}$ As Shawn Michelle Smith writes of lynching in the Jim Crow United States, the act of documenting the crime was both part of and proof of the white supremacist violence: "Making a photograph became part of the ritual, helping to objectify and dehumanize the victims... [Photographs] expanded the domain of lynching to those absent, extending the culturally divisive function of lynching beyond the purview of any particular mob." Dora Apel and Shawn Michelle Smith, Lynching Photographs (Berkeley: University of California Press, 2007), 16-17. See also Grace Elizabeth Hale, Making Whiteness: The Culture of Segregation in the South, 1890-1940 (New York: Vintage Books, 1999), chap. 5.

${ }^{110}$ Several academic sources join the chorus of voices who misattribute this quotation to Mark Twain. For examples, see Aaron David Miller, "For America, An Arab Winter," The Wilson Quarterly 35, no. 3 (2011), 36 and Donald F. Moores, “History Doesn't Repeat Itself, But It Sure Does Rhyme (With Apologies to Mark Twain)," American Annals of the Deaf 142, no. 1 (1997). 
Benjamin, Walter. Illuminations: Essays and Reflections. Edited by Hannah Arendt. Translated by Harry Zohn. New York: Schocken Books, 1969.

Bernstein, Patricia. The First Waco Horror: The Lynching of Jesse Washington and the Rise of the NAACP, New ed. College Station: Texas A\&M University Press, 2006.

Browning, Robert. "My Last Duchess." In The Norton Anthology of Poetry, 5thed., edited by Margaret Ferguson, Mary Jo Salter, and Jon Stallworthy, 1012-1013. New York: W.W. Norton \& Co., 2005.

Bulens, A., and G. Bulens, eds. An Answer to Mark Twain. Brussels: Bulens Brothers, 1907.

Campt, Tina M. Listening to Images: An Exercise in Counterintuition, Reprint ed. Durham: Duke University Press Books, 2017. https://doi.org/10.1215/9780822373582

Casement, Roger. Correspondence and Report from His Majesty's Consul at Boma Respecting the Administration of the Independent State of the Congo. London: Harrison \& Sons, 1904.

Cohen, Adam. Imbeciles: The Supreme Court, American Eugenics, and the Sterilization of Carrie Buck. Reprint ed. New York: Penguin Books, 2017.

Cole, Teju. "Getting Others Right." New York Times Magazine, June 13, 2017. Accessed July 23, 2017, https://www.nytimes.com/2017/06/13/magazine/getting-others-right.html.

--------. "The White-Savior Industrial Complex." The Atlantic, March 21, 2012. Accessed July 25, 2017, https://www.theatlantic.com/international/archive/2012/03/the-white-saviorindustrial-complex/254843/.

Conrad, Joseph. Heart of Darkness, 5th ed., edited by Paul B. Armstrong. New York: W.W. Norton \& Co., 2016.

--------. Tales of Unrest, 1st ed., edited by Allan H. Simmons and J. H. Stape. New York: Cambridge University Press, 2012.

Civil Rights Congress. We Charge Genocide: The Crime of the Government Against the Negro People, 1970 republication ed. New York: International Publishers Co., Inc., 1951. https://archive.org/ stream/We-Charge-Genocide-1970/We-Charge-Genocide-1970 djvu.txt.

Doyle, Sir Arthur Conan. The Crime of the Congo. New York: Doubleday, Page \& Company, 1909.

Elder, R. Bruce. Harmony and Dissent: Film and Avant-Garde Art Movements in the Early Twentieth Century. Waterloo: Wilfrid Laurier University Press, 2010.

Fehrenbach, Heide, and Davide Rodogno, eds. Humanitarian Photography: A History. New York: Cambridge University Press, 2015. https://doi.org/10.1017/CBO9781107587694

Festa, Lynn. "Humanity without Feathers." Humanity: An International Journal of Human Rights, Humanitarianism, and Development 1, no. 1 (2010), 3-27. https://doi.org/10.1353/ hum.2010.0007

Franklin, John Hope. George Washington Williams: A Biography. Durham: Duke University Press, 1998.

Ginzburg, Ralph. 100 Years of Lynchings. Baltimore: Black Classic Press, 1962.

Grant, Kevin. "The Limits of Exposure: Atrocity Photographs in the Congo Reform Campaign." In Humanitarian Photography: A History, edited by Heide Fehrenbach and Davide Rodogno, 64-88. New York: Oxford University Press, 2015. https://doi.org/10.1017/ CBO9781107587694.004

Hale, Grace Elizabeth. Making Whiteness: The Culture of Segregation in the South, 1890-1940. New York: Vintage, 1999.

Harris, Alice, and Mark Twain. Nsala of Wala, the Part of the Picture Which Has Been Shown in King Leopold's Soliloquy by Mark Twain. 1904/1905. Wikimedia Commons. Accessed July 22, 2017. https://commons.wikimedia.org/wiki/File:Nsala of Wala-Mark Twain, Soliloquy.jpg.

Hartman, Saidiya V. Lose Your Mother: A Journey Along the Atlantic Slave Route, 1st ed. New York: Farrar, Straus and Giroux, 2007.

--------. Scenes of Subjection: Terror, Slavery, and Self-Making in Nineteenth-Century America, 1st ed. New York: Oxford University Press, 1997.

Hasian, Jr., Marouf. "Alice Seeley Harris, the Atrocity Rhetoric of the Congo Reform Movements, and the Demise of King Léopold's Congo Free State." Atlantic Journal of Communication 23, no. 3 (2015), 178-192. https://doi.org/10.1080/15456870.2015.1047495 
Hawkins, Hunt. "Mark Twain's Involvement with the Congo Reform Movement: 'A Fury of Generous Indignation."' New England Quarterly 51, no. 2 (1978), 147-175. https://doi. org $/ 10.2307 / 364304$

Heym, Stefan. Introduction to King Leopold's Soliloquy, by Mark Twain, 11-27. New York: International Publishers, 2014.

Hochschild, Adam. King Leopold's Ghost: A Story of Greed, Terror, and Heroism in Colonial Africa. First Mariner Books ed. Boston: Houghton Mifflin, 1999.

Jones, Adam. Genocide: A Comprehensive Introduction, 3rd ed. New York: Routledge, 2017.

Kim, Linda. "A Law of Unintended Consequences: United States Postal Censorship of Lynching Photographs." Visual Resources 28, no. 2 (2012), 171-193. https://doi.org/10.1080/01973762. 2012.678812

Lemkin, Raphael. Lemkin on Genocide, edited by Stephen Leonard Jacobs. Lanham: Lexington Books, 2012.

Leyshon, Cressida. "This Week in Fiction: Zadie Smith." The New Yorker, February 3, 2013. Accessed July 20, 2017, http://www.newyorker.com/books/page-turner/this-week-in-fiction-zadiesmith-2.

Lydon, Jane. Photography, Humanitarianism, Empire. New York: Bloomsbury Academic, 2016.

Malkki, Liisa H. "Children, Humanity, and the Infantilization of Peace." In In the Name of Humanity: The Government of Threat and Care, edited by Ilana Feldman and Miriam Ticktin, 58-85. Durham: Duke University Press Books, 2010. https://doi.org/10.1215/9780822393221-003

Mamdani, Mahmood. When Victims Become Killers: Colonialism, Nativism, and the Genocide in Rwanda. Princeton: Princeton University Press, 2002.

Mbembe, Achille, and Libby Meintjes. “Necropolitics." Public Culture 15, no. 1 (2003), 11-40. https:// doi.org/10.1215/08992363-15-1-11

Meierhenrich, Jens, ed. Genocide: A Reader, 1st ed. Oxford: Oxford University Press, 2014.

Miller, Aaron David. "For America, An Arab Winter." The Wilson Quarterly 35, no. 3 (2011): 36-42.

Moores, Donald F. "History Doesn't Repeat Itself, But It Sure Does Rhyme (With Apologies to Mark Twain)." American Annals of the Deaf 142, no. 1 (1997): 3-4. https://doi.org/10.1353/ aad.2012.0225

Morel, Edmund Dene. King Leopold's Rule in Africa. New York: Funk and Wagnalls Co., 1905. http://archive.org/details/kingleopoldsrul00moregoog.

Morel, Edmund Dene, and Harry Johnston. Red Rubber; the Story of the Rubber Slave Trade Flourishing on the Congo in the Year of Grace 1906, 2nd ed. New York: Nassau Print, 1906.

Moten, Fred. "Black Mo'nin'." In Loss: The Politics of Mourning, edited by David L. Eng, David Kazanjian, and Judith Butler, 59-76. Berkeley: University of California Press, 2002.

. In the Break: The Aesthetics of the Black Radical Tradition. Minneapolis: University of Minnesota Press, 2003.

Nudelman, Franny. John Brown's Body: Slavery, Violence, \& the Culture of War. Chapel Hill: The University of North Carolina Press, 2004.

Oxford English Dictionary, s.v. "Imagine, V." Accessed July 20, 2017. http://www.oed.com.proxy. lib.duke.edu/view/Entry/91651.

-------. “Phantasmagoria, N." Accessed July 20, 2017. http://www.oed.com.proxy.lib.duke.edu/ view/Entry/142184.

Patterson, William L. The Man Who Cried Genocide: An Autobiography, 1st ed. New York: International Publishers, 1971.

Patterson, William L., ed. We Charge Genocide: The Crime of Government Against the Negro People. New York: International Publishers, 1970.

Pavlakis, Dean. British Humanitarianism and the Congo Reform Movement, 1896-1913. New York: Routledge, 2016. https://doi.org/10.4324/9781315570136

Peffer, John. "Snap of the Whip/Crossroads of Shame: Flogging, Photography, and the Representation of Atrocity in the Congo Reform Campaign." Visual Anthropology Review 24, no. 1 (2008), 55-77.

Riis, Jacob. How the Other Half Lives: Studies Among the Tenements of New York, 2nd ed. Boston: Bedford/St. Martins, 2011. 
Rodríguez, Dylan. “Inhabiting the Impasse Racial/Racial-Colonial Power, Genocide Poetics, and the Logic of Evisceration." Social Text 33, no. 3 (2015), 19-44. https://doi.org/10.1215/01642472$\underline{3125689}$

Shakespeare, William. The Tragedy of Hamlet, Prince of Denmark, Edited Walter Cohen, Stephen Greenblatt, Jean E. Howard, and Katharine Eisaman Maus, 1659-1759. New York: W.W. Norton \& Co., 1997.

Sliwinski, Sharon. Human Rights in Camera. Chicago: University of Chicago Press, 2011. https://doi. org/10.7208/chicago/9780226762784.001.0001

-------. "The Childhood of Human Rights: The Kodak on the Congo." Journal of Visual Culture 5, no. 3 (2006), 333-363. https://doi.org/10.1177/1470412906070514

Smith, Shawn Michelle, and Sharon Sliwinski, eds. Photography and the Optical Unconscious. Durham: Duke University Press Books, 2017. https://doi.org/10.1215/9780822372998

Smith, Zadie. "The Embassy of Cambodia." The New Yorker, February 11, 2013. Accessed July 21, 2017, http://www.newyorker.com/magazine/2013/02/11/the-embassy-of-cambodia.

Sontag, Susan. Regarding the Pain of Others, 1st ed. New York: Picador, 2004.

Thompson, T. Jack. Light on Darkness?: Missionary Photography of Africa in the Nineteenth and Early Twentieth Centuries. Grand Rapids: Eerdmans Publishing, 2012.

-------. "Light on the Dark Continent: The Photography of Alice Seely Harris and the Congo Atrocities of the Early Twentieth Century." International Bulletin of Missionary Research 26, no. 4 (2002), 146-149. https://doi.org/10.1177/239693930202600401

Totten, Samuel, and Paul R. Bartrop, eds. The Genocide Studies Reader, 1st ed. New York: Routledge, 2009.

Twain, Mark. A Connecticut Yankee in King Arthur's Court. New York: Oxford University Press, 1996. - Following the Equator and Anti-Imperialist Essays. New York: Oxford University Press, 1996.

-------. King Leopold's Soliloquy: A Defense of His Congo Rule, 2nd ed. Boston: The P.R. Warren Co., 1905. http://diglib1.amnh.org/articles/kls/twain.pdf.

Twomey, Christina. "Framing Atrocity: Photography and Humanitarianism." In Humanitarian Photography: A History, edited by Heide Fehrenbach and Davide Rodogno, 47-63. New York: Cambridge University Press, 2015.

“U.S. Accused in U.N. of Negro Genocide." The New York Times. December 18, 1951.

Wells-Barnett, Ida B. The Red Record: Tabulated Statistics and Alleged Causes of Lynching in the United States. 1895. https://www.gutenberg.org/files/14977/14977-h/14977-h.htm.

Wexler, Laura. Tender Violence: Domestic Visions in an Age of U.S. Imperialism, New ed. Chapel Hill: The University of North Carolina Press, 2000.

Whitman, James Q. Hitler's American Model: The United States and the Making of Nazi Race Law. Princeton: Princeton University Press, 2017. https://doi.org/10.1515/9781400884636

Williams, George Washington. "An Open Letter to His Serene Majesty Leopold II, King of the Belgians and Sovereign of the Independent State of Congo, by Colonel the Honorable Geo. W. Williams, of the United States of America." In George Washington Williams: A Biography, by John Hope Franklin, 243-254. Durham: Duke University Press, 1985.

Wuliger, Robert. "Mark Twain on King Leopold's Soliloquy." American Literature 25, no. 2 (1953), 234-237.

Zeller, Bob. The Civil War in Depth: History in 3-D. Book and Access ed. San Francisco: Chronicle Books, 1997. 